\title{
Development of Gel for Aedes aegypti Repellent With Combination of Cinnamon Oil (Cinnamomum burmannii Blume) and Fennel Oil (Foeniculum vulgare Mill)
}

\author{
Evah Sohipah, ${ }^{1}$ Anny Victor Purba, ${ }^{2}$ Ratna Djamil ${ }^{3}$
}

\begin{abstract}
Background/Aim: Aim of this study was to develop efficient mosquito repellent by combining fennel oil (Foeniculum vulgare Mill) and cinnamon oil (Cinnamomum burmannii Blume) in a gel preparation form.

Methods: Effectiveness of each oil and its combination as viral repellents was tested by the World Health Organization's Pesticide Evaluation Scheme (WHOPES) method. Repellent was prepared in gel form. Evaluation of gel preparation included organoleptic properties, homogeneity, $\mathrm{pH}$, viscosity, flow properties, acute skin irritation test and effectiveness test as mosquito repellent.

Results: The mosquito protection test for cinnamon oil showed that cinnamon oil was most effective at concentration of $15 \%$ (96.85\%), and fennel oil at $24 \%$ concentration (79.26\%). Within 6 hours, gel made of $24 \%$ fennel oil and $15 \%$ cinnamon oil combination gave protection against $53.49 \%$ mosquitoes.

Conclusion: The combination of cinnamon oil and fennel oil can be formulated into gel form with satisfying physical and chemical characteristics and effectiveness against Aedes aegypti mosquitoes for 6 hours.
\end{abstract}

Key words: Gel; Aedes aegypti; Cinnamon oil; Fennel oil; Repellent.
(1) Faculty of Pharmacy, Pancasila University, Jakarta 12640, Indonesia.

(2) Departement of Biological Pharmacy, Faculty of Pharmacy, Pancasila University, Jakarta 12640, Indonesia.

(3) Departement of Pharmaceutical Technology, Faculty of Pharmacy, Pancasila University, Jakarta 12640, Indonesia.

Correspondence: EVAH SOHIPAH

Email: evasohivah28@gmail.com

\section{ARTICLE INFO}

Received: 13 May 2020

Revision received: 26 June 2020 Accepted: 28 June 2020

\section{Introduction}

Aedes mosquitoes are a type of mosquito that is usually found in the tropics. Its name is derived from the Greek word aedes, which means "unpleasant". These mosquitoes are more than unpleasant, since they spread some dangerous diseases such as dengue fever. This species can often be found in Asia. Its specific characteristic is black and white legs. Aedes aegypti mosquitoes are also known as dengue propagators..$^{1-3}$

Currently, the most available mosquito repellents on the market contain of anti-mosquito spray and anti-mosquito lotion are mostly made from di- ethyl-meta-toluamide (DEET) chemicals. Chemical insecticide has an impact on a residue and its active ingredients are difficult to decompose in nature. These negative effects need to be avoided by replacing chemical insecticide with natural insecticide. $^{4}$

Based on the type form of mosquito repellent products on the market, mosquito repellents such as mosquito coil gel are classified as superior products. They can be used anytime and anywhere. In addition, gel formulations have many advantages when compared with other semi-solid prepara-

Copyright $\odot 2020$ Sohipah et al. This is an open access article distributed under the Creative Commons Attribution License (CC BY), which permits unrestricted use, distribution, and reproduction in any medium, provided the original work is properly cited. This article should be cited as follows: Sohipah E, Purba AV, Djamil R. Development of Gel for Aedes aegypti repellent with combination of cinnamon oil (Cinnamomum burmannii Blume) and fennel oil (Foeniculum vulgare Mill). Scr Med 2020;51(3):198-202. 
tions such as creams or ointments. Gelled preparations have good active absorption capability on the skin, it is easy washed it away with water, they are highly adhesive when used on hair and skin without clogging the pores. ${ }^{5,6}$

Plant ingredients such as fennel oil (Foeniculum vulgare Mill) contain anethole that can serve as a repellent. Anethole is a group of essential oil compounds that have a very distinctive aroma and flavour that mosquitoes do not like. Cinnamon oil (Cinnamomum burmannii Blume) has cinnamaldehyde compounds that are toxic to mosquitoes. This substance has a potential to be used to make mosquito gel preparations, because the smell and taste is not favoured by mosquitoes. Cinnamon oil exhibits antibacterial, antifungal, antioxidant and anti-thrombotic effects. The combination of both plants is expected to work synergistically as a mosquito repellent.7,8

\section{Methods}

\section{Material}

The material consists of eggs from Aedes aegypti L mosquitoes, Carbopol U21 (dope lubrizol), propylene glycol (The Dow Chemical Company), triethanolamine (Merck), phenoxyethanol (Clariant), $C$ burmannii blume oil, $F$ vulgare oil and aqua.

\section{Methods}

The concentration of cinnamon oil and fennel oil was used in the formula that is determined based on preliminary test results, fennel oil was used in $2 \%, 4 \%, 6 \%, 24 \%$ concentration and cinnamon oil was used in $5 \%, 10 \%, 15 \%$ concentration. In this research concentration of combination of $15 \%$ cinnamon oil and $24 \%$ fennel oil was used to assess the effective dose of cinnamon oil and fennel oil test effectiveness mosquito repellent performed following the procedure recommended by the current guidelines by the World Health Organization's Pesticide Evaluation Scheme (WHOPES). The effectiveness test of mosquito repellent using human subjects' method has been chosen according to actual conditions of use. ${ }^{9}$

\section{Maintenance of Aedes aegypti eggs}

Aedes aegypti eggs were inserted into plastic cups or bowls containing water for 2-3 days to drip down the larvae. During the development period the larvae were fed in pellets until the pupa phase was formed. The larval stage usually lasted 6-8 days to become the pupa, then the pupa was transferred into a bowl of water and left in the cage for 1-3 days to develop into an adult mosquito. Female mosquitoes were separated from male mosquitoes and fed in the form of sugar water., 10

\section{Preparation of gel formulation}

Carbopol U21 was dispersed in distilled water with $500 \mathrm{rpm}$ stirrer speed for 24 hours. Phenoxyethanol was dissolved in propylene glycol and stirred with a stir bar until the homogeneous mixture was produced. The developed Carbopol U21 was neutralised with triethanolamine stirred with a stir bar until homogeneity. All bases were stirred at $200 \mathrm{rpm}$ for 30 minutes, then the fennel oil and the cinnamon oil were added and stirred until homogeneity. Then, evaluation of anti-mosquito gel was performed. ${ }^{11-13}$

\section{Evaluation of physical and chemical prepa- rations gel}

Physical and chemical properties such as organoleptic properties (colour and odour), homogeneity and $\mathrm{pH}$ of gel were determined. Determination of viscosity and flow properties were performed with a Brookfield viscometer at a rate of $0.5 ; 1$; $2.5 ; 5 ; 10$; and $20 \mathrm{rpm}$ and turn $20 ; 10 ; 5 ; 2.5 ; 2$; 1 ; and $0.5 \mathrm{rpm}$. The result obtained was plotted against shear stress (dyne $/ \mathrm{cm}^{2}$ ) and shear rate velocity (rpm). Viscosity checks were performed for 3 months at $40{ }^{\circ} \mathrm{C}$ temperature storage, at room temperature and at temperature of 400 ${ }^{\circ} \mathrm{C} .{ }^{14}$

\section{Effectiveness of gel protection}

Before and after the experiment each test area of the forearm volunteers was washed with soap and rinsed with water, then dried. The left arm as control was inserted into the mosquito coil, observed and the number of mosquitoes perched within the brackets within 5 minutes were recorded. When mosquito was perched, the test had begun, and after 5 minutes the arm was carefully removed from the mosquito cage. Then the right leg was smeared with gel and placed into the mosquito coat to be observed for 5 minutes. Arms and legs should not move during the test. Number of mosquitoes perched on the volunteer arms and legs were recorded. Observation lasted for 6 hours, with continuous monitoring and recordings every hour (on start, 1st, 2nd, 3rd, 4th, 5th and 6th hour). The number of mosquitoes that alighted were recorded as well.

\section{Stability test}

The gel stability test was performed and it includ- 
ed organoleptic properties (colour and odour), homogeneity, $\mathrm{pH}$, viscosity and flow properties. Evaluated at low temperature $\left(4 \pm 2{ }^{\circ} \mathrm{C}\right)$ and room temperature $\left(25 \pm 2{ }^{\circ} \mathrm{C}\right)$ for 3 months with evaluation every 2 weeks, and high temperature $(40 \pm 2$ ${ }^{\circ} \mathrm{C}$ ) for 4 weeks, with once a week evaluation. ${ }^{15-16}$

\section{Irritation test}

Toxicity test was performed by acute dermal irritation test on rabbit. Rabbits used in test were white male rabbits, 4 - 6 months of age, weight between 1.8 - $2 \mathrm{~kg}$. Regulation of the head of BPOM No. 7 Year 2014 concerning the non-clinical in vivo toxicity test was considered and it was complied with the regulation. ${ }^{17}$

\section{Results}

The results of effectiveness test of Aedes aegypti mosquito cinnamon oil and fennel oil

The mosquito protection test for cinnamon oil is most effective at concentration of $15 \%$ and its activity protection was $96.85 \%$ (Table 1).

Table 1: Result of effectiveness test of protection power of cinnamon oil to Aedes aegypti mosquitoes

\begin{tabular}{|c|c|c|c|c|c|}
\hline \multirow{2}{*}{ Days } & \multirow{2}{*}{ Replication } & \multirow{2}{*}{ Alcohol } & \multicolumn{3}{|c|}{ Concentration } \\
\hline & & & $5 \%$ & $10 \%$ & $15 \%$ \\
\hline \multirow{3}{*}{1} & 1 & 24 & 6 & 2 & 1 \\
\hline & II & 24 & 4 & 3 & 2 \\
\hline & III & 23 & 4 & 2 & 1 \\
\hline \multirow{3}{*}{2} & I & 25 & 8 & 2 & 0 \\
\hline & $\|$ & 23 & 8 & 2 & 1 \\
\hline & III & 27 & 5 & 1 & 0 \\
\hline \multirow{3}{*}{3} & 1 & 25 & 4 & 1 & 1 \\
\hline & $\|$ & 27 & 6 & 2 & 1 \\
\hline & III & 24 & 3 & 1 & 0 \\
\hline \multicolumn{2}{|c|}{ Average mosquitoes on hand } & 24.67 & 5.33 & 1.78 & 0.80 \\
\hline \multicolumn{2}{|c|}{ Activity protection } & & $78.38 \%$ & $92.79 \%$ & $96.85 \%$ \\
\hline
\end{tabular}

Table 2: Test results of effectiveness of fennel oil protection against Aedes aegypti mosquitoes

\begin{tabular}{|c|c|c|c|c|c|c|}
\hline \multirow{2}{*}{ Days } & \multirow{2}{*}{ Replication } & \multirow{2}{*}{ Alcohol } & \multicolumn{4}{|c|}{ Concentration } \\
\hline & & & $2 \%$ & $4 \%$ & $6 \%$ & $24 \%$ \\
\hline \multirow{3}{*}{1} & I & 21 & 14 & 11 & 12 & 5 \\
\hline & II & 20 & 14 & 11 & 10 & 3 \\
\hline & III & 19 & 12 & 10 & 13 & 4 \\
\hline \multirow{3}{*}{2} & I & 24 & 15 & 13 & 14 & 5 \\
\hline & ॥I & 22 & 16 & 12 & 11 & 4 \\
\hline & IIII & 20 & 13 & 12 & 11 & 5 \\
\hline \multirow{3}{*}{3} & 1 & 19 & 16 & 14 & 13 & 5 \\
\hline & ॥I & 22 & 14 & 13 & 11 & 4 \\
\hline & III & 21 & 15 & 14 & 10 & 4 \\
\hline \multicolumn{2}{|c|}{ Average mosquitoes on hand } & 20.89 & 14.33 & 12.22 & 11.67 & 4.33 \\
\hline \multicolumn{3}{|c|}{ Activity protection } & $31.38 \%$ & $41.49 \%$ & $44.15 \%$ & $79.26 \%$ \\
\hline
\end{tabular}

The mosquito protection test for fennel oil is most effective at $24 \%$ concentration and its activity protection was $79.26 \%$ (Table 2).

The test of mosquito protection from combination cinnamon oil and fennel oil for 6 hours compared with positive control (Figure 1).

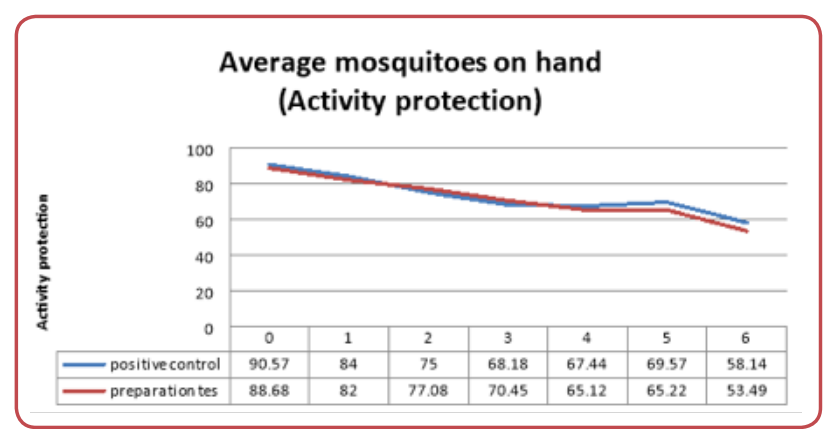

Figure 1. Result of activity protection combination of cinnamon oil and fennel oil mosquito repellent

Table 3: Formulation design of the mosquito repellent gel

\begin{tabular}{|c|c|c|}
\hline Materials & $\frac{\text { Concentration }(\%)(b / b)}{\text { Formula }}$ & Function \\
\hline Fennel 0il & 24 & Active ingredients \\
\hline Cinnamon Oil & 15 & Active ingredients \\
\hline Carbopol U 21 & 3,01 & Thickener \\
\hline Propylene glycol & 6,03 & Humectan \\
\hline Triethanolamin & 0,5 & pH adjuster \\
\hline phenoxyethanol & 0,2 & Preservative \\
\hline Aquadest & 51,26 & solven \\
\hline
\end{tabular}

\section{Formulation design}

Table 3 contains the chemical composition of the repellent gel based on fennel oil and cinnamon oil.

\section{Evaluation of gel preparations}

\section{Organoleptic}

The mosquito repellent gel was made to show a homogeneous physical appearance, clear white colour and pleasant aroma.

The results of viscosity testing and flow properties

The viscosity of gel on third temperature after storage for 12 weeks decreased. At $5 \mathrm{rpm}$ speed using spindle No. 3 temperature $400{ }^{\circ} \mathrm{C}$ has viscosity of 7,050 centipoise (cP), temperature 250 ${ }^{\circ} \mathrm{C}$ has viscosity $3,600 \mathrm{cP}$, and temperature $40{ }^{\circ} \mathrm{C}$ has viscosity 2,550 cP (Figure 2). 


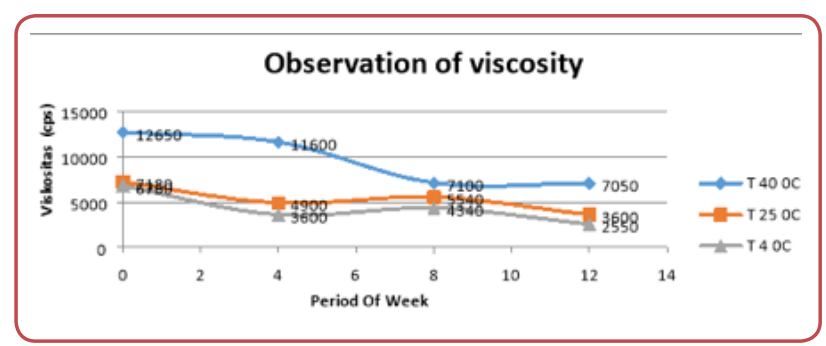

Figure 2. Graph of changes in viscosity values to three temperatures during 12 weeks.

\section{Storage flow properties}

The pseudo plastic flow properties begin at zero and there is no yield value. Viscosity decreases with increasing rate of shearing. Increased shearing stress causes the regularity of the polymer thereby reducing the resistance and further increasing the rate of share in subsequent shearing stress (Figure 3).

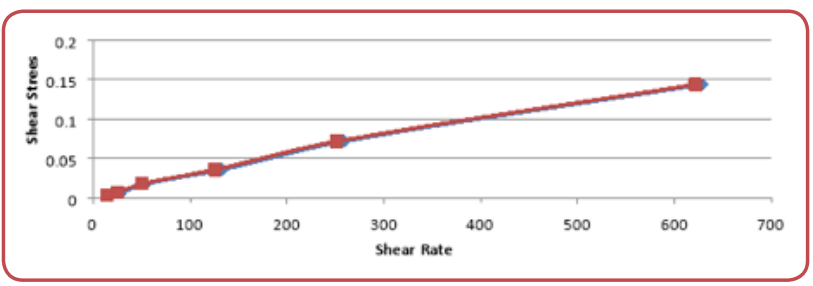

Figure 3. Rheology pseudo plastic

\section{$\mathrm{pH}$}

$\mathrm{pH}$ of gel was $6.00-6.25$. The addition of a combination of cinnamon oil and fennel oil can cause a decrease in the $\mathrm{pH}$.

The result of mosquito repellent stability test The mosquito repellent formulas are stable at temperature $\left(25 \pm 2{ }^{\circ} \mathrm{C}\right)$ and cold temperature (4 $\pm 2{ }^{\circ} \mathrm{C}$ ) with homogeneous physical appearance, clear white colour, and aromatic viscosity of 7180 - 2550 cps, pseudoplastic flow properties pH 6.00 up to 6.25 (skin pH 4.5 to 6.5 ).

Table 4: Response of rabbits to irritation caused by mosquito repellent gel containing fennel oil and cinnamon oil administered over $72 \mathrm{~h}$

\begin{tabular}{lc}
\hline Irritation response category in rabbits & Score \\
\hline No Irritation & 0 \\
\hline Very Low Irritation & 1 \\
\hdashline Low Irritation & 2 \\
\hdashline Middle Irritation & 0 \\
\hline High irritation and exfoliation & 0 \\
\hline
\end{tabular}

Result of irritation test

The combination of mosquito repellent oil gel and fennel oil resulted in mild irritation of the skin of experimental animals after application for 3 consecutive days $(72 \mathrm{~h})$ with a mild irritation index of 2 (Table 4).

\section{Discussion}

With observation for 6 hours, combination of fennel oil in $24 \%$ concentration and cinnamon oil in $15 \%$ concentration, gave protection from 53.49 $\%$ Aedes aegypti mosquitoes. Chemical insecticides due to their longevity have a great impact on environment. If there is a possibility of finding a natural insecticide that is effective it is worth the effort.

This decrease in viscosity can be caused by storage packaging. It is assumed that it causes the gel to absorb water from the environment so that the volume of water in the formula increases. In addition, the arrangement of initially irregular molecules into long axes in the flow direction may result in some of the solvents binding to lose molecules, thereby causing a decrease in viscosity.

pH of gel was $6.00-6.25$. The addition of a combination of cinnamon oil and fennel oil can cause a decrease in the $\mathrm{pH}$ which is welcomed since acid repels mosquitoes.

\section{Conclusion}

Based on the observation and test of protection power it can be concluded that the combination of fennel oil and cinnamon oil are effective repellents against Aedes aegypti mosquitoes for 6 $h$. The combination of cinnamon oil and fennel oil can be formulated into gel preparations and meets the physical and chemical requirements.

\section{Acknowledgements}

None.

\section{Conflict of interest}

None. 


\section{References}

1. Widoyono. Penyakit Tropis [Tropical disease]. Jakarta: Erlangga; 2011. Indonesian.

2. Setyowati EA. Biologi nyamuk Aedes aegypti sebagai vector demam berdarah dengue [Aedes aegypti mosquito as a vector of dengue hemorrhagic fever]. Purwokerto: Universitas Jendral Soedirman; 2013. Indonesian.

3. Soedarto S. Buku Ajar Parasitologi Kedokteran [A handbook of medical parasitology]. Jakarta: Sagung Seto; 2011. Indonesian.

4. Kardinan A, Prasetya RA. Tanaman pengusir dan pembasmi nyamuk [Mosquito repellent plants] [Internet]. Vol. I, Agro Media Pustaka. 2005. 2-5 p. Available from: https://books. google.co.id/books?hl=id\&lr=\&id=LJ2oCgAAQ$B A J \& o i=f n d \& p g=P R 2 \& d q=b u k u+$ tentang +vektor+nyamuk\&ots=F9ZXmovXWD\&sig=-kb-zZtsceyNQP2toQg9AT4cQfU\&redir_esc =y\#v=onepage \&q=buku tentang vektor nyamuk\&f=false\%0Ahttps://books. google.co.id/books?id=LJ2oCgAA. Indonesian.

5. Nunik SA, Singgih S SP. Prostrate Sebagai Repellan untuk nyamuk Aedes aegypti [Prostrate as a repellent for Aedes aegypti]. Kesehat Masy 1997;25(7):482-3. Indonesian.

6. Rusmin, D. \& M. Adas (Foeniculum vulgare) Tanaman yang berpotensi dikembangkan sebagai bahan obat alami [The potential plant to be developed as natural medicine]. War Peneliti dan Pengemb Tanam Ind 2007;X13(2):21-3. Indonesian.

7. Departemen Kesehatan Republik Indonesia. Materia Medika Indonesia [Indonesia Medical Material]. J Chem Information Modeling 2013. Indonesian.

8. Endarini LH. Farmakognisi dan Fitokimia. Kementrian Kesehat Republik Indonesia.;2016.
9. World Health Organization. Guidelines for efficacy testing of mosquito repellents for human skin. Control of Neglected Tropical Diseases WHO Pesticide Evaluation Scheme. 2009.

10. Ishartadiati K. Aedes aegypti as the vector of dangue hemorrhagic fever. J Ilm Kedokt wijaya kusuma 2012;3(2):2-3.

11. Reynold JE. Martindale The Extra Pharmacopiea 28th ed. London: The Pharmaceutical Press; 1982. p. 1121.

12. Wade AWP. Handbook of pharmaceutical excipients. 6th ed. Washington: American Pharmaceutical Association; 2009. p. 89-226.

13. Peraturan Kepala BPOM RI Nomor 19 Tahun 2015 Tentang Persyaratan Teknis Bahan Kosmetik [Government Regulation number 19/2015 Bout technical ingredients of Cosmetics]. 2015. Indonesian.

14. Martin, A, Swarbick J, Cammarata A. Farmasi Fisik Jilid II (Edisi Ke-3) [Physical Pharmacy II]. Jakarta: UI Press; 1983. Indonesian.

15. ASEAN Guideline on Stability Study of Drug Product. 9th ACCSQ- PPWG Meeting, Philippines. 2018.

16. ICH. Guidelines, Stability testing of new drug substances and products. The European Agency for the evaluation of Medical Products. Human Medicine Evaluation Units. 1993.

17. BPOM RI. Peraturan Kepala Badan Pengawas Obat Dan Makanan Republik Indonesia Nomor 7 Tahun 2014 Tentang Pedoman Uji Toksisitas Nonklinik Secara In Vivo. Peratur Kepala Badan Pengawas Obat Dan Makanan Republik Indones Nomor 7 Tahun 2014. [Regulation Of The Head Of The Drug And Food Control Of The Republic Of Indonesia Number 7 Of 2014 Concerning Guidelines For Nonclinical Toxicity Testing]. 2014. Indonesian. 